\title{
The implications of evolutionary changes in the dendritic morphology of cerebellar Purkinje cells for information processing
}

\author{
Kirsty Kidd ${ }^{1 *}$, Hugo Cornelis ${ }^{2}$, James M Bower ${ }^{2,3}$, Daniel Polani ${ }^{1}$, Neil Davey ${ }^{1}$, Volker Steuber ${ }^{1}$ \\ From Twenty Second Annual Computational Neuroscience Meeting: CNS*2013 \\ Paris, France. 13-18 July 2013
}

The dendritic morphology of neurons has been a focus of study in computational neuroscience for many years (e.g. [1]), but it is rare that the morphology of the same cell has been compared across different species. This study compares the morphology and resulting predicted passive electrical properties of cerebellar Purkinje cells obtained from a variety of different animal species, both mammalian and non-mammalian. The comparison is based on single cell reconstructions incorporated into the GENESIS simulation platform. For comparison purposes, all simulations were performed using values for membrane conductance and axial resistivity applied in previous models of mammalian Purkinje cells [2]. In addition to quantifying differences in morphology and expected passive electrical properties, the possible information processing capability of each species of Purkinje cell was evaluated using information theoretical techniques such as those used previously to quantify relationships between input and output [3]. The resulting information theoretical measures are then used to compare the performance of each cell, and to identify compensatory mechanism that could preserve the information processing capabilities in the presence of the morphological changes that occur during evolution.

\footnotetext{
Author details

'School of Computer Science, University of Hertfordshire, Hatfield, Hertfordshire, AL10 9AB, UK. ${ }^{2}$ University of Texas Health Science Center, San Antonio, Texas, 78245, USA. ${ }^{3}$ Barshop Institute for Longevity and Aging Studies, San Antonio, Texas, 78245, USA.

Published: 8 July 2013

* Correspondence: k.kidd2@herts.ac.uk

'School of Computer Science, University of Hertfordshire, Hatfield, Hertfordshire, AL10 9AB, UK

Full list of author information is available at the end of the article
}

References

1. Mainen ZF, Sejnowski TJ: Influence of dendritic structure on firing pattern in model neocortical neurons. Nature 1996, 382:363-366.

2. Rapp M, Segev I, Yarom Y: Physiology, morphology and detailed passive models of guinea-pig cerebellar Purkinje cells. J Physiol 1994, 474:101-118.

3. Coop AD, Cornelis H, Santamaria F: Dendritic excitability modulates dendritic information processing in a Purkinje cell model. Front Comput Neurosci 2010, 4(6):1-10.

doi:10.1186/1471-2202-14-S1-P373

Cite this article as: Kidd et al: The implications of evolutionary changes in the dendritic morphology of cerebellar Purkinje cells for information processing. BMC Neuroscience 2013 14(Suppl 1):P373.

Submit your next manuscript to BioMed Central and take full advantage of:

- Convenient online submission

- Thorough peer review

- No space constraints or color figure charges

- Immediate publication on acceptance

- Inclusion in PubMed, CAS, Scopus and Google Scholar

- Research which is freely available for redistribution

Submit your manuscript at www.biomedcentral.com/submit
C Bïomed Central
C Biomed Central

(c) 2013 Kidd et al; licensee BioMed Central Ltd. This is an Open Access article distributed under the terms of the Creative Commons Attribution License (http://creativecommons.org/licenses/by/2.0), which permits unrestricted use, distribution, and reproduction in any medium, provided the original work is properly cited. 